\title{
Tasas de crecimiento somático de tortuga carey, Eretmochelys imbricata, en el Parque Nacional Natural Gorgona, Colombia, entre 2004 y 2018
}

\section{Somatic growth rates of the Hawksbill Turtle, Eretmochelys imbricata, in Gorgona Natural National Park, Colombia, between 2004 and 2018}

\author{
Mariana Cañas-Uribe ${ }^{1}$, Luis F. Payán ${ }^{2}$, Diego F. Amorocho ${ }^{3}$ y Vivian P. Páez ${ }^{l}$ \\ $\begin{array}{llll}\text { (iD) } 0000-0002-8797-278 X & \text { (iD } 0000-0003-2326-6533 & \text { (iD } 0000-0001-9089-6098 & \text { (iD } 0000-0002-9777-1981\end{array}$
}

\author{
1. Grupo Herpetológico de Antioquia (GHA), Instituto de Biología, Universidad de Antioquia, Medellín, Colombia.mcaur94@gmail.com*, \\ vivianpaez1@gmail.com \\ 2. Parques Nacionales Naturales de Colombia, Cali, Colombia.estacioncientificagorgona@gmail.com \\ 3. Centro de Investigación para el Manejo Ambiental y el Desarrollo (CIMAD).amorocho.diego@gmail.com \\ * Autora de correspondencia.
}

\section{RESUMEN}

a tortuga carey, Eretmochelys imbricata, se encuentra a nivel global en peligro crítico de extinción, y la información demográfica en el Océano Pacífico Oriental es limitada. Por esta razón, esta investigación evalúa las tasas de crecimiento somático en una agregación de individuos inmaduros de tortuga carey empleando el método de captura-marca-recaptura en los arrecifes coralinos de Playa Blanca y la Azufrada en el Parque Nacional Natural Gorgona, Colombia. Entre 2004 y 2018 se realizaron 89 capturas de 49 individuos de tortuga carey. El largo curvo del caparazón promedio (LCC) obtenido fue de 41,6 cm (rango $32-58 \mathrm{~cm}$ ) y el largo recto del caparazón promedio (LRC) fue de $39,1 \mathrm{~cm}$ (rango 30,0-54,1 cm), lo que muestra que estos arrecifes son áreas de forrajeo importantes para individuos inmaduros de esta especie. El índice de condición corporal promedio fue de 1,3 (rango 1,0-1,5). Esto sugiere que las condiciones ambientales mantienen en buen estado la salud de esta agregación. Usando el modelo de crecimiento de von Bertalanffy y estableciendo una talla máxima $\left(\mathrm{L}_{\infty}\right)$ de $63 \mathrm{~cm}$ de LCC (donde se obtiene el menor coeficiente de variación), se estimó una $k$ de 0,081 y una tasa anual de crecimiento promedio de $1,5 \pm 1,8 \mathrm{~cm} /$ año. Esto indica que los individuos en esta agregación estarían alcanzando una LCC de $63 \mathrm{~cm}$ entre los 33 y 34 años, talla cercana a la de madurez sexual en la región del Pacífico oriental (aproximadamente $66 \mathrm{~cm} \mathrm{LCC).} \mathrm{Lo} \mathrm{anterior} \mathrm{ratifica} \mathrm{la} \mathrm{vulnerabilidad} \mathrm{de} \mathrm{esta} \mathrm{especie} \mathrm{debido} \mathrm{a} \mathrm{las} \mathrm{lentas} \mathrm{tasas}$ de crecimiento somático y madurez sexual tardía. Se sugiere que los esfuerzos de conservación para esta especie deben ser a largo plazo para procurar su recuperación, en vista de que especies con estas características tienden a expresar tasas de crecimiento poblacional muy bajas.

PALABRAS CLAVE: tortugas marinas, Cheloniidae, Pacífico Oriental Tropical, índice de condición corporal, áreas de forrajeo

\section{ABSTRACT}

$\mathrm{T}$

The Hawksbill Turtle, Eretmochelys imbricata, is globally assessed as Critically Endangered, and information in the Eastern Pacific Ocean is limited. For this reason, this investigation evaluated the somatic growth rates in an immature hawksbill sea turtle aggregation using capture-mark-recapture on the coral reefs at Playa Blanca and La Azufrada in the Gorgona Natural National Park, Colombia. Between 2004 and 2018, we made 89 captures of 49 hawksbill individuals. The mean curved carapace length (CCL) obtained was $41.6 \mathrm{~cm}$ (range 32-58 cm), and the mean straight-line carapace length (SCL) was $39.1 \mathrm{~cm}$ (range 30.0-54.1 cm), showing these reefs to be critical foraging grounds for immature individuals. The mean body condition index was 1.3 (range 1.0-1.5), suggesting that environmental conditions maintain the health of this aggregation in good conditions. Using the von Bertalanffy growth model and establishing a maximum length $\left(\mathrm{L}_{\infty}\right)$ of $63 \mathrm{~cm}$ of CCL (where the lowest coefficient of variation is obtained), we estimated a $k$ of 0.081 and an average annual growth rate of 1.5 $\pm 1.8 \mathrm{~cm} /$ year. This indicated that individuals in this aggregation reach a CCL of $63 \mathrm{~cm}$ at 33-34 years of age, close to the sexual maturity for the tropical eastern Pacific region (approximately $66 \mathrm{~cm} \mathrm{CCL}$ ). This indicates the vulnerability of this species due to its late maturity and slow growth. Because of this, conservation efforts for this species must be long-term to ensure its recovery, since species with these characteristics tend to express very low population growth rates.

KEY WORDS: sea turtle, Cheloniidae, Tropical Eastern Pacific, body condition index, foraging areas 


\section{INTRODUCCIÓN}

La tortuga carey, Eretmochelys imbricata, se encuentra clasificada a nivel global en Peligro Crítico (CR A2bd; Mortimer y Donnelly, 2008), ya que se ha evidenciado una reducción de más de $80 \%$ de sus poblaciones en las últimas tres generaciones (UICN, 2012). Esta reducción se debe principalmente al uso de su caparazón en la elaboración de joyas y artesanías, al consumo de su carne y sus huevos y a la pérdida de hábitats de forrajeo y de anidación (National Research Council, 1990; Llamas et al., 2017). Hasta hace una década se creía que la especie había sido eliminada de la región del Océano Pacífico Oriental (OPO; Campbell, 2014), pero recientemente se han encontrado hábitats de forrajeo y playas de anidación en esta región (Altamirano et al., 2010; Gaos et al., 2012; Campbell, 2014; ChacónChaverri et al., 2015; Llamas et al., 2017).

El ciclo de vida de las tortugas carey luego de nacer las crías y entrar al mar comienza en hábitats oceánicos. Al alcanzar la etapa juvenil, los individuos migran a hábitats de forrajeo neríticos (Lutz y Musick, 1997) donde se encuentran principalmente asociados a arrecifes coralinos y otros fondos duros, como consecuencia de sus requerimientos de hábitat y alimento (Bjorndal y Bolten, 2010). Allí, aparentemente, permanecen como residentes durante un periodo prolongado de tiempo y las condiciones locales determinan su supervivencia (Blumenthal et al., 2009). Se ha documentado que los individuos inmaduros tienen una talla de reclutamiento en hábitats neríticos de entre 20 a $35 \mathrm{~cm}$ de Longitud Curva del Caparazón (LCC; Lutz y Musick, 1997; Blumenthal et al., 2009; Bjorndal y Bolten, 2010). Al alcanzar la madurez sexual, se desplazan a otras áreas de forrajeo y reproducción (Lutz y Musick, 1997) donde se encuentran asociadas a arrecifes coralinos y a estuarios de manglar (Lutz y Musick, 1997; ChacónChaverri et al., 2015; Gaos et al., 2017). La madurez sexual en el OPO se ha determinado con la talla mínima registrada para hembras anidantes en El Salvador y Nicaragua, de $66 \mathrm{~cm}$ de LCC (Altamirano et al., 2010; Chacón-Chaverri et al., 2015). En el Caribe (Puerto Rico) se identificaron machos adultos con una Longitud Recta del Caparazón (LRC) mayor a $68 \mathrm{~cm}$ (Diez y van Dam, 2002).

Debido a que se ha observado la permanencia de las tortugas carey juveniles a las áreas de forrajeo durante periodos prolongados (Blumenthal et al., 2009; Carrión-Cortez et al., 2013; Wood et al., 2013; Llamas et al., 2017) y estas áreas son vulnerables a contaminación y cambios climáticos (Muñoz y

\section{INTRODUCTION}

The hawksbill turtle, Eretmochelys imbricata, is classified globally as Critically Endangered (CR A2bd; Mortimer and Donnelly, 2008) since there has been a reduction of more than $80 \%$ of its populations in the last three generations (IUCN, 2012). This reduction is mainly due to the use of their shell in jewelry and handicraft production, the consumption of their meat and eggs, and the loss of foraging and nesting habitats (National Research Council, 1990; Llamas et al., 2017). Until a decade ago it was believed that the species had been eliminated from the Eastern Pacific Ocean region (EPO; Campbell, 2014), but recently foraging habitats and nesting beaches have been found in this area (Altamirano et al., 2010; Gaos et al., 2012; Campbell, 2014; Chacón-Chaverri et al., 2015; Llamas et al., 2017).

The life cycle of hawksbill turtles after hatching and entering the sea begins in oceanic habitats. Upon reaching the juvenile stage, individuals migrate to neritic foraging habitats (Lutz and Musick, 1997) where they are mainly associated with coral reefs and other hard bottoms, as a consequence of their habitat and food requirements (Bjorndal and Bolten, 2010). There, they remain as residents for an extended period, and local conditions determine their survival (Blumenthal et al., 2009). Immature individuals have been documented to have a recruitment size in neritic habitats of between 20 to $35 \mathrm{~cm}$ Curved Carapace Length (CCL; Lutz and Musick, 1997; Blumenthal et al., 2009; Bjorndal and Bolten, 2010). Upon reaching sexual maturity, they move to other foraging and reproduction areas (Lutz and Musick, 1997) where they are associated with coral reefs and mangrove estuaries (Lutz and Musick, 1997; ChacónChaverri et al., 2015; Gaos et al., 2017). Sexual maturity in the EPO has been determined with the minimum size reported for nesting females in El Salvador and Nicaragua, of $66 \mathrm{~cm}$ CCL (Altamirano et al., 2010; Chacón-Chaverri et al., 2015). In the Caribbean (Puerto Rico), adult males with a Straight Carapace Length (SCL) greater than $68 \mathrm{~cm}$ were identified (Diez and van Dam, 2002).

Due to the permanence of juvenile hawksbill turtles in foraging areas for long periods (Blumenthal et al., 2009; Carrión-Cortez et al., 2013; Wood et al., 2013; Llamas et al., 2017) and these areas are vulnerable to pollution and climate changes (Muñoz and Zapata, 2013), it is important to diagnose the physical status of the animals, to assess the dynamics in the health of these populations. 
Zapata, 2013), es importante diagnosticar el estado físico de los animales con el fin de evaluar la dinámica en la salud de estas poblaciones. Para esto, se utiliza con frecuencia el índice de condición corporal (ICC), el cual tiene un poder predictivo significativo en modelos de crecimiento somático de la tortuga verde (Chelonia mydas) y también ha sido usado en estudios de calidad del hábitat en tortugas carey (Bjorndal y Bolten, 2010). Algunos promedios de los valores de ICC registrados para estas tortugas en el Caribe, en donde se ha evidenciado que los individuos se encuentran en buen estado físico, varían entre 1,16 en el acantilado Mona (Diez y van Dam, 2002) hasta 1,25 $\pm 0,17$ en Little Cayman (Blumenthal et al., 2009), mientras que este índice no ha sido registrado en el OPO.

Por otra parte, cuantificar las tasas de crecimiento corporal de los individuos permite estimar el tiempo que les toma alcanzar la talla y/o la edad mínima de madurez sexual, la cual es un atributo fundamental para comprender sus historias de vida y el potencial de crecimiento poblacional, así como para desarrollar estrategias de manejo (van Dam, 2000; Bell y Pike, 2012). En estudios realizados en la Gran Barrera de Arrecifes (GBR) en Australia se ha observado un patrón en las tasas de crecimiento que sugiere un ajuste al modelo de von Bertalanffy para tortugas carey (Chaloupka y Limpus, 1997; Bell y Pike, 2012). En la población de tortuga carey en Hawái se evidenció que el modelo de von Bertalanffy se ajustaba mejor a los datos: se estimó un coeficiente de crecimiento característico (k) de 0,09 y una tasa de crecimiento corporal anual para individuos inmaduros de $4,59 \mathrm{~cm} /$ año $(\mathrm{SD}=2,04)$ por medio de esqueletocronología (Snover et al., 2012). Este modelo de crecimiento usualmente se ajusta mejor a los datos de crecimiento corporal en tortugas, en las cuales frecuentemente las tasas de crecimiento de los juveniles son mayores que en adultos, y permite proyectar cuánto tiempo tardan los individuos en llegar a la madurez sexual (Bjorndal y Zug, 1995).

La mayoría de los estudios sobre crecimiento para la tortuga carey no utilizan el modelo de crecimiento de von Bertalanffy, sino que registran la tasa de crecimiento corporal (TCC). En estos estudios se observa una gran variación espacial en las TCC estimadas para diferentes categorías de talla y sexo, en diferentes regiones del Pacífico oriental, occidental y del Caribe (Limpus, 1992; Boulon, 1994; Chaloupka y Limpus, 1997; Diez y van Dam, 2002; Blumenthal et al., 2009; Bell y Pike, 2012; Wood et al., 2013; Zárate, 2015; Bjorndal et al., 2016; Llamas et al.,
For this, the body condition index (BCI) is frequently used, which has significant predictive power in somatic growth models of the green sea turtle (Chelonia mydas) and has also been used in studies of habitat quality in hawksbills. (Bjorndal and Bolten, 2010). Some averages of the BCI values recorded for these turtles in the Caribbean, where it has been evidenced that individuals are in good physical condition, vary from 1.16 at Mona Cliff (Diez and van Dam, 2002) to $1.25 \pm 0.17$ in Little Cayman (Blumenthal et al., 2009), while this index has not been reported in the EPO region.

On the other hand, quantifying the body growth rates of individuals allows estimating the time it takes them to reach a height and/or the minimum age of sexual maturity, which is a fundamental attribute to understand their life histories and growth potential population, as well as for develop management strategies (van Dam, 2000; Bell and Pike, 2012). In studies carried out in the Great Barrier Reef (GBR) in Australia, a pattern in growth rates has been observed that suggests an adjustment to the von Bertalanffy model for hawksbill turtles (Chaloupka and Limpus, 1997; Bell and Pike, 2012). In the hawksbill turtle population in Hawaii, it was evidenced that the von Bertalanffy model was a better fit for the data: it estimated a characteristic growth coefficient $(k)$ of 0.09 and an annual body growth rate for immature individuals of $4.59 \mathrm{~cm} /$ year $(\mathrm{SD}=2.04)$ utilizing skeletochronology (Snover et al., 2012). This growth model usually has a better fit to the body growth data in turtles, in which juvenile growth rates are frequently higher than in adults and allows projecting how long it takes individuals to reach sexual maturity (Bjorndal and Zug, 1995).

Most growth studies for the hawksbill turtle do not use the von Bertalanffy growth model, but instead, report body growth rate (BGR). In these studies, a large spatial variation is observed in estimated BGRs for different categories of height and sex, in different regions of the Eastern, Western and Caribbean Pacific (Limpus, 1992; Boulon, 1994; Chaloupka y Limpus, 1997; Diez y van Dam, 2002; Blumenthal et al., 2009; Bell y Pike, 2012; Wood et al., 2013; Zárate, 2015; Bjorndal et al., 2016; Llamas et al., 2017). Additionally, in the Pacific region, Bjorndal and Bolten (2010) showed that hawksbill turtles have monotonic and relatively slow growth rates, which means that the growth rate increases in the same degree of variation, without having maximum peaks while Diez and van Dam (2002) showed a non-monotonic pattern in 
2017). Adicionalmente, en la región del Pacífico, Bjorndal y Bolten (2010) evidenciaron que las tortugas carey tienen tasas de crecimiento monotónicas y relativamente lentas, lo cual quiere decir que la tasa de crecimiento va aumentando en el mismo grado de variación, sin tener picos máximos, mientras que Diez y van Dam (2002) evidenciaron un patrón no monotónico en la región Caribe, con tasas de crecimiento más bajas en individuos pequeños y un pico de crecimiento mayor en categorías de talla entre los 30 y $40 \mathrm{~cm}$ de LRC.

El OPO es considerado como una de las Unidades de Manejo Regional de mayor amenaza para la tortuga carey y no se tiene aún conocimiento sobre algunos parámetros demográficos fundamentales para evaluar planes de manejo de la especie en esta región (Wallace et al., 2011). Por ello, en esta investigación se evaluaron algunos de estos parámetros, como son la proporción de diferentes categorías de talla, el ICC y la tasa de crecimiento somático, para la agregación de tortuga carey en los arrecifes coralinos Playa Blanca y La Azufrada del Parque Natural Nacional Gorgona (PNNG) Colombia, por medio de datos obtenidos a través del método de captura-marca-recaptura entre 2004 y 2018. Esta información contribuye al mejoramiento del monitoreo de tortugas marinas realizado en el PNNG y aporta nuevo conocimiento sobre la especie en el OPO, lo que, a su vez, genera información esencial para los planes de conservación y de manejo en la región.

\section{ÁREA DE ESTUDIO}

El muestreo fue ejecutado en el PNNG $\left(02^{\circ} 55^{\prime} 45^{\prime \prime}\right.$ $03^{\circ} 00^{\prime} 55^{\prime \prime} \mathrm{N}$ y $78^{\circ} 09^{\prime} 00^{\prime \prime}-78^{\circ} 14^{\prime} 30^{\prime \prime} \mathrm{W}$ ), ubicado en el departamento del Cauca, en el océano Pacífico, al suroccidente de Colombia (Amorocho et al., 2015), en dos arrecifes de borde bien desarrollados: Playa Blanca y La Azufrada, ubicados al costado oriental (sotavento) de la isla (Figura 1). Los dos arrecifes poseen en general una estructura y una zonación similares (Muñoz y Zapata, 2013). Playa Blanca tiene un área de 9,9 ha, $930 \mathrm{~m}$ de largo y entre 60 y $230 \mathrm{~m}$ de ancho, mientras que La Azufrada tiene un área de 11,2 ha, $780 \mathrm{~m}$ de largo y entre 80 y $180 \mathrm{~m}$ de ancho, ambos con profundidades que no exceden $10 \mathrm{~m}$ en marea alta (Muñoz y Zapata, 2013).

\section{MATERIALES Y MÉTODOS}

\section{Captura-marca-recaptura}

La toma de datos para este análisis inició en 2004 con el apoyo del CIMAD (Centro de Investigación para el the Caribbean region, with lower growth rates in small individuals and with a higher growth peak in size categories between 30 and $40 \mathrm{~cm}$ in height SCL.

The EPO is considered one of the Regional Management Units with the greatest threat to the hawksbill turtle and there is still no knowledge of some fundamental demographic parameters to evaluate management plans for the species in this region (Wallace et al., 2011). Therefore, in this research, some of these parameters were evaluated, such as the proportion of different size categories, the $\mathrm{BCI}$ and the somatic growth rate, for the hawksbill turtle aggregation in the coral reefs Playa Blanca and La Azufrada of the Gorgona National Natural Park (GNNP) Colombia, through data obtained through the capture-mark-recapture method between 2004 and 2018. This information contributes to the improvement of the monitoring of sea turtles carried out in the GNNP and contributes new knowledge about the species in the EPO, generating in turn essential information for conservation and management plans in the region.

\section{STUDY AREA}

The sampling was carried out at the GNNP $\left(02^{\circ} 55^{\prime} 45^{\prime \prime}-03^{\circ} 00^{\prime} 55^{\prime \prime} \mathrm{N}\right.$ and $\left.78^{\circ} 09^{\prime} 00^{\prime \prime}-78^{\circ} 14^{\prime} 30^{\prime \prime} \mathrm{W}\right)$, located in the department of Cauca in the Pacific Ocean in southwestern Colombia (Amorocho et al., 2015), on two well-developed edge reefs: Playa Blanca and La Azufrada, located on the eastern (leeward) side of the island (Figure 1). Both reefs generally have a similar structure and zoning (Muñoz and Zapata, 2013). Playa Blanca has an area of 9.9 ha, $930 \mathrm{~m}$ long and between 60 and $230 \mathrm{~m}$ wide, while $\mathrm{La}$ Azufrada has an area of 11.2 ha, $780 \mathrm{~m}$ long and between 80 and $180 \mathrm{~m}$ wide, both with depths that do not exceed $10 \mathrm{~m}$ at high tide (Muñoz and Zapata, 2013).

\section{MATERIALS AND METHODS}

\section{Capture-mark-recapture}

Data collection for this analysis began in 2004 with the support of CIMAD (Center for Research for Environmental Management and Development) and WWFColombia (World Wide Fund for Nature) and from 2008 to 2018 the GNNP (Amorocho et al., 2015). These episodes were not systematic, since a transect, a periodicity, or a specific time for the searches was not defined, nor is there a record of sampling events without individuals captured. 


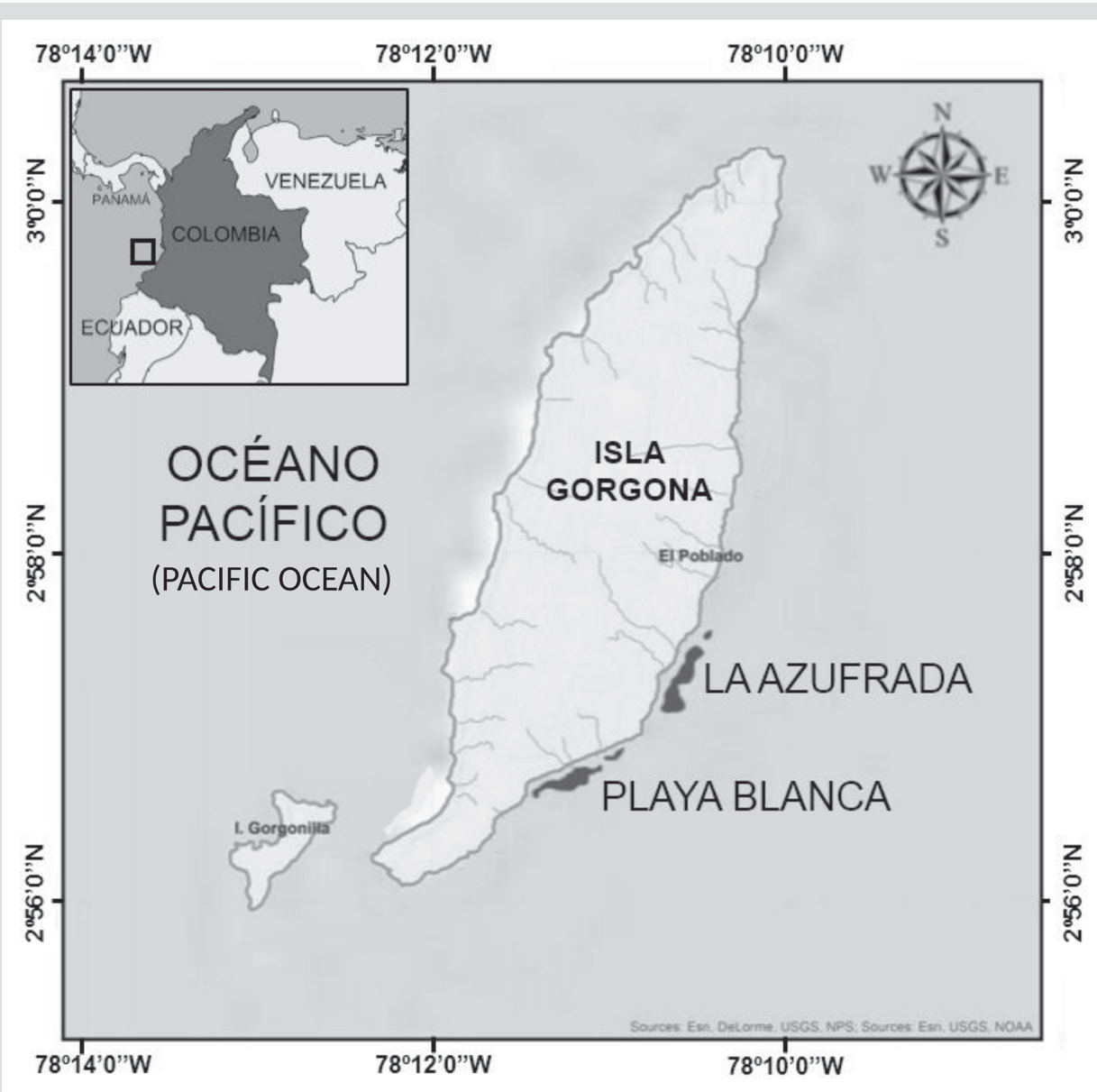

Figura 1. Mapa del Parque Nacional Natural Gorgona y ubicación de los arrecifes coralinos Playa Blanca y La Azufrada.
Figure 1. Map of the Gorgona National Natural Park and location of the Playa Blanca and La Azufrada coral reefs.
Manejo Ambiental y el Desarrollo) y el WWF-Colombia (Fondo Mundial para la Naturaleza) y desde 2008 hasta 2018 del PNNG (Amorocho et al., 2015). Estos episodios no fueron sistemáticos, ya que no se definió un transecto, una periodicidad, ni un tiempo específico para las búsquedas, ni se tiene registro de los eventos de muestreo sin individuos capturados.

En ambos arrecifes, el personal encargado del monitoreo realizó la búsqueda de los individuos a pulmón (apnea). Cada episodio de búsqueda duró entre 20 y $50 \mathrm{~min}$ y en su mayoría se realizaron entre 20:00 y 21:00 h, periodo durante el cual las tortugas descansan, lo cual facilita su captura. Todos los individuos fueron medidos, pesados, marcados y liberados en la playa El Poblado, ubicada a una distancia aproximada de 3305 y $1407 \mathrm{~m}$ de los arrecifes de Playa Blanca y La Azufrada, respectivamente. Las medidas morfométricas tomadas fueron LRC y LCC, desde el escudo nucal hasta el punto medio de la muesca posterior entre los escudos supracaudales (Bolten, 2000). Las medidas rectas
In both reefs, the personnel in charge of monitoring searched for individuals by lung (freediving). Each search episode lasted between 20 and $50 \mathrm{~min}$ and most of them took place between 20:00 and 21:00 h, during which time the turtles rested, which facilitates their capture. All individuals were measured, weighed, tagged, and released at El Poblado beach, located at a distance of approximately 3305 and $1407 \mathrm{~m}$ from the reefs of Playa Blanca and La Azufrada, respectively. The morphometric measurements taken were SCL and CCL, measured from the nuchal shield to the midpoint of the posterior notch between the supracaudal shields (Bolten, 2000). The straight measurements were taken with the help of a caliper (with a precision of $0.1 \mathrm{~cm}$ ), the curved measurements with a flexible tape measure (with a precision of $0.1 \mathrm{~cm}$ ), and the weight was taken with a continental brand Roman scale (with a precision of $0.5 \mathrm{~kg}$ ). Each individual was marked with a metal tag (Monel or Inconel, n. ${ }^{\circ}$ 681), on the second scale of the anterior fin, previously disinfected with povidone-iodine (Balazs, 2000). 
se tomaron con la ayuda de una forcípula (con una precisión de $0,1 \mathrm{~cm}$ ), las medidas curvas con una cinta métrica flexible (con una precisión de $0,1 \mathrm{~cm}$ ) y el peso con una balanza romana marca Continental (con una precisión de $0,5 \mathrm{~kg}$ ). Cada individuo fue marcado con una placa metálica (Monel o Inconel, n. ${ }^{\circ}$ 681) en la segunda escama de la aleta anterior, previamente desinfectada con yodopovidona (Balazs, 2000).

\section{Análisis de datos}

Se agruparon las tortugas por categorías de talla, determinadas arbitrariamente de la siguiente manera: categoría 1 (30 cm $<\mathrm{LCC}<34,9 \mathrm{~cm})$, categoría $2(35 \mathrm{~cm}$ $<$ LCC $<39,9 \mathrm{~cm})$, categoría $3(40 \mathrm{~cm}<$ LCC $<44,9 \mathrm{~cm})$, categoría $4(45 \mathrm{~cm}<\mathrm{LCC}<49,9 \mathrm{~cm})$ y categoría 5 (LCC $\geq 50 \mathrm{~cm})$. La caracterización de la estructura poblacional para cada arrecife se halló con la proporción de tortugas presentes en cada categoría de talla. Para determinar si se presentaba alguna diferencia en estas proporciones entre arrecifes, se realizó una prueba exacta de Fisher (1934). El ICC se calculó con el peso y la LRC por medio de la siguiente ecuación (Bjorndal y Bolten, 2010):

$$
\text { ICC }=\left[\frac{\text { peso }}{L R C^{3}}\right] \times 10^{4}
$$

Se calculó el crecimiento somático por medio del modelo de von Bertalanffy para la agregación de tortugas carey de ambos arrecifes, con las medidas de LCC de la primera y la última captura porque estas son usadas con mayor frecuencia en estudios de tortugas marinas, lo cual facilita la comparación con otros trabajos. Para calcular el coeficiente característico de crecimiento corporal $(k)$, el cual describe cuán rápido crece un animal desde su nacimiento hasta su máxima longitud, se usó la siguiente ecuación (Munro, 1982):

$$
k=\frac{\left[\log _{e}\left(L_{\infty}-L_{m}\right)-\log _{e}\left(L_{\infty}-L_{r}\right)\right]}{(r-m)}
$$

donde:

$\mathrm{L}_{\infty}$ es la longitud máxima que pueden alcanzar los individuos de la población (en este caso, se calculó para longitudes entre 60 y $66 \mathrm{~cm}$ ),

$\mathrm{L}_{\mathrm{m}}$ es la longitud curva del caparazón (LCC) en la primera captura,

$\mathrm{L}_{\mathrm{r}}$ es la LCC en la última recaptura,

$r$ y $m$ son las fechas de la última recaptura y primera captura, respectivamente, $\mathrm{y}$

$e$ es la base del logaritmo natural.

\section{Analysis of data}

The turtles were grouped by size categories, arbitrarily determined as follows: category $1(30 \mathrm{~cm}$ $<\mathrm{CCL}<34.9 \mathrm{~cm})$, category $2(35 \mathrm{~cm}<\mathrm{CCL}<39.9 \mathrm{~cm})$, category $3(40 \mathrm{~cm}<\mathrm{CCL}<44.9 \mathrm{~cm})$, category 4 $(45 \mathrm{~cm}<\mathrm{CCL}<49.9 \mathrm{~cm})$ and category $5(\mathrm{CCL} \geq 50 \mathrm{~cm})$. The characterization of the population structure for each reef was found with the proportion of turtles present in each size category. To determine if there was a difference in these proportions between reefs, an exact test of Fisher (1934) was performed. The BCI was calculated with the weight and the SCL, through the following equation (Bjorndal and Bolten, 2010):

$$
B C I=\left[\frac{\text { weight }}{S C L^{3}}\right] \times 10^{4}
$$

Somatic growth was calculated utilizing the von Bertalanffy model for the aggregation of hawksbill turtles from both reefs, with the CCL measurements of the first and last catch because these are used more frequently in studies of sea turtles, which facilitates comparison with other studies. To calculate the characteristic body growth coefficient $(k)$, which describes how fast an animal grows from its birth to its maximum length, the following equation was used (Munro, 1982):

$$
k=\frac{\left[\log _{e}\left(L_{\infty}-L_{m}\right)-\log _{e}\left(L_{\infty}-L_{r}\right)\right]}{(r-m)}
$$

Where:

$\mathrm{L}_{\infty}$ is the maximum length that individuals in the population can reach (in this case, it was calculated for lengths between 60 and $66 \mathrm{~cm}$ ),

$\mathrm{L}_{\mathrm{m}}$ is the curved carapace length (CCL) at the first capture, $\mathrm{L}_{\mathrm{r}}$ is the CCL at the last recapture,

$r$ and $m$ are the dates of the last recapture and first capture, respectively, and

$e$ is the base of the natural logarithm.

This coefficient was calculated for all the recaptured individuals. From these data, their average and the coefficient of variation $(\mathrm{CV})$ was calculated.

Subsequently, utilizing the von Bertalanffy model, the length corresponding to each year of life of the individuals in this population $\left(\mathrm{L}_{\mathrm{t}}\right)$ was estimated, from 
Este coeficiente se calculó para todos los individuos recapturados. A partir de estos datos, se calculó su promedio y el coeficiente de variación $(C V)$. Posteriormente, por medio del modelo de von Bertalanffy, se estimó la longitud correspondiente a cada año de vida de los individuos en esta población $\left(\mathrm{L}_{\mathrm{t}}\right)$, desde el año 0 , en el que el individuo mide aproximadamente $4 \mathrm{~cm}$ LCC (Altamirano et al., 2010), hasta alcanzar la longitud máxima. En este estudio se fijó una longitud máxima de $63 \mathrm{~cm}$ LCC porque a este tamaño se obtuvo el menor $C V$ y porque es un valor cercano a $66 \mathrm{~cm}$ de LCC, la talla mínima de madurez sexual registrada para las hembras en el OPO (Altamirano et al., 2010). Con estos valores se estimó el tiempo en años que tardarían los individuos de la población monitoreada en el PNNG en alcanzar la talla mínima de madurez.

$$
L_{t}=L_{\infty}\left\{1-e^{\left[-k\left(t-t_{0}\right)\right]}\right\}+\begin{aligned}
& \text { tamaño } \\
& \text { promedio al nacer }
\end{aligned}
$$

Donde:

$\mathrm{t}_{0}$ es el tiempo de la eclosión, $\mathrm{y}$

Talla promedio al nacer $=4 \mathrm{~cm}$

Además, se calculó la tasa de crecimiento corporal (TCC), siendo esta la diferencia entre la longitud de la última captura $\left(\mathrm{L}_{\mathrm{r}}\right)$ y la primera $\left(\mathrm{L}_{\mathrm{m}}\right)$ sobre el tiempo $\left(\mathrm{TCC}=\left(\mathrm{L}_{\mathrm{r}}-\mathrm{L}_{\mathrm{m}}\right) /\right.$ año; Lutz y Musick, 1997).

\section{RESULTADOS}

Desde 2004 hasta 2018 se realizaron 66 episodios de búsqueda nocturnos exitosos (al menos un individuo capturado), 44 en el arrecife Playa Blanca y 22 en La Azufrada. Se capturaron 49 individuos de tortuga carey, de los cuales se recapturaron 19 (38,8\%) al menos dos veces (nueve individuos fueron capturados dos veces, seis individuos tres veces, dos individuos cuatro veces, un individuo cinco veces y un individuo diez veces). Durante las inmersiones, se observaron las tortugas principalmente descansando (81,0\%), explorando (15,2\%) y en menor proporción alimentándose $(3,8 \%)$. Además, todas las recapturas (menos un individuo) se presentaron siempre en el mismo arrecife. Los promedios y desviaciones estándar de las medidas morfométricas en la primera captura se pueden observar en la Tabla 1.

En la Tabla 2 se pueden observar las medidas para cada una de las cinco categorías de talla en cada arrecife. Ya que los individuos no superan los $66 \mathrm{~cm}$ de LCC, son considerados inmaduros; además, ninguno de los individuos year 0 , in which the individual measures approximately $4 \mathrm{~cm}$ CCL (Altamirano et al., 2010), until reaching the maximum length. In this study, a maximum length of $63 \mathrm{~cm} \mathrm{CCL}$ was set, because at this size the lowest $C V$ was obtained, and because it is a close value to $66 \mathrm{~cm} \mathrm{CCL}$, the minimum size of sexual maturity reported for females in the EPO (Altamirano et al., 2010). With these values, the time in years that it would take the individuals of the monitored population in the GNNP to reach the minimum maturity size was estimated.

$$
L_{t}=L_{\infty}\left\{1-e^{\left[-k\left(t-t_{0}\right)\right]}\right\}+\begin{aligned}
& \text { average } \\
& \text { size at birth }
\end{aligned}
$$

Where:

$\mathrm{t}_{0}$ is the hatching time, and

Average size at birth is $4 \mathrm{~cm}$

Also, the body growth rate (BGR) was calculated, this being the difference between the length of the last capture $\left(\mathrm{L}_{\mathrm{r}}\right)$ and the first $\left(\mathrm{L}_{\mathrm{m}}\right)$ over time $\left(\mathrm{BGR}=\left(\mathrm{L}_{\mathrm{r}}-\mathrm{L}_{\mathrm{m}}\right)\right.$ year; Lutz and Musick, 1997).

\section{RESULTS}

From 2004 to 2018, 66 successful nocturnal search episodes were carried out (at least one individual captured), 44 in the Playa Blanca reef, and 22 in La Azufrada. 49 individuals of hawksbill turtles were captured, of which 19 $(38.8 \%)$ were recaptured at least twice (nine individuals were captured twice, six individuals three times, two individuals four times, one individual five times, and one individual ten times). During the dives, the turtles were observed mainly resting (81.0\%), exploring (15.2\%), and to a lesser extent feeding (3.8\%). Furthermore, all recaptures (except one individual) always occurred on the same reef. The averages and standard deviations of the morphometric measurements in the first capture can be observed in Table 1.

In Table 2 you can see the measurements for each of the five size categories in each reef. Since the individuals do not exceed $66 \mathrm{~cm}$ of CCL they are considered immature; also, none of the captured individuals exhibited evident secondary sexual characteristics, such as a greater length of the tail in males (Bolten, 2000). The category with the highest proportion of individuals was category 2 (CCL between 35 and $39.9 \mathrm{~cm}$ ) with $32.7 \%$, followed by category 3 (CCL between 40 and $44.5 \mathrm{~cm}$ ) with $30.6 \%$ (Figure 2). Category 1 (between 30 and $34.9 \mathrm{~cm} \mathrm{CCL}$ ) 
Tabla 1. Promedio y rango de medidas morfométricas tomadas en la primera captura de tortugas carey, Eretmochelys imbricata, en el PNNG.
Table 1. Average and range of morphometric measurements taken in the first capture of hawksbill turtles, Eretmochelys imbricata, in the GNNP.

\begin{tabular}{|c|c|c|c|}
\hline Medida/Measurement & Media/Mean \pm SD & Rango/Range & \multicolumn{1}{c|}{49} \\
\hline LCC/CCL & $41.6 \pm 5.4 \mathrm{~cm}$ & $32.0-58.0 \mathrm{~cm}$ & 49 \\
LRC/SCL & $39.1 \pm 5.0 \mathrm{~cm}$ & $30.0-54.1 \mathrm{~cm}$ & 49 \\
ACC/CCW & $36.4 \pm 4.8 \mathrm{~cm}$ & $28.2-49.0 \mathrm{~cm}$ & 49 \\
ARC/SCW & $31.0 \pm 3.7 \mathrm{~cm}$ & $24.2-40.9 \mathrm{~cm}$ & 46 \\
\hline Peso/Weight & $8.2 \pm 3.6 \mathrm{~kg}$ & $3.5-23.0 \mathrm{~kg}$ & 4 \\
\hline
\end{tabular}

capturados exhibió características sexuales secundarias evidentes, como una mayor longitud de cola en machos (Bolten, 2000). La categoría con una mayor proporción de individuos fue la 2 (LCC entre 35 y $39,9 \mathrm{~cm}$ ) con $32,7 \%$, seguida por la 3 (LCC entre 40 y 44,5 cm) con 30,6\% (Figura 2). La categoría 1 (entre 30 y $34,9 \mathrm{~cm}$ LCC) representó $12,2 \%$ de la población y la 5 (LCC $\geq 50 \mathrm{~cm}$ ) tal solo $8,2 \%$ de la población. De los 49 individuos capturados, 19 estaban en el arrecife La Azufrada y 30 en Playa Blanca. En La Azufrada se observa un mayor porcentaje de individuos en la categoría 2 mientras que en Playa Blanca un mayor porcentaje de individuos en la 3, como se puede observar en la Figura 3. No se encontró una diferencia significativa en las proporciones de categorías entre los arrecifes (prueba exacta de Fisher: $P=0,314)$. El ICC promedio $\left(10^{-4} \mathrm{~kg} / \mathrm{cm}^{3}\right)$ de las capturas realizadas en ambos arrecifes fue de 1,3 \pm $0,11(n=46$, rango $1,0-1,5)$.

Tabla 2. Promedio de las medidas morfométricas de las tortugas carey, Eretmochelys imbricata, capturadas entre 2004 y 2018 para cada categoría de talla y arrecife coralino. LCC: longitud curva del caparazón. LRC: longitud recta del caparazón. SD: desviación estándar. * Se hallaron dos outliers en las medidas de peso, uno en La Azufrada en la categoría 3 y otro en Playa Blanca en la categoría 2. represented $12.2 \%$ of the population and category 5 (CCL $\geq 50 \mathrm{~cm}$ ) represented only $8.2 \%$ of the population. Of the 49 individuals captured, 19 were in the La Azufrada reef and 30 in Playa Blanca. In La Azufrada a higher percentage of individuals is observed in category 2, while in Playa Blanca a higher percentage of individuals in category 3 , such as can be seen in Figure 3. No significant difference was found in category proportions between reefs (Fisher's exact test: $P=0.314)$. The average BCI $\left(10^{-4} \mathrm{~kg} / \mathrm{cm}^{3}\right)$ of all the catches made on both reefs was $1.3 \pm 0.11(n=46$, range 1.0-1.5).

In the somatic growth analysis, the lowest $C V$ was obtained with a maximum length of $63 \mathrm{~cm} \mathrm{CCL}(C V=0.96)$, and it yielded an average characteristic coefficient of body growth $(k)$ of 0.081 . The von Bertalanffy growth curve indicated that individuals in this population would reach

Table 2. Average morphometric measurements of hawksbill turtles, Eretmochelys imbricata, were captured between 2004 and 2018 for each size category and coral reef. CCL: curved carapace length. SCL: straight carapace length. SD: standard deviation. * Two outliers were found in the weight measurements, one in La Azufrada in category 3 and another in Playa Blanca in category 2.

\begin{tabular}{|c|c|c|c|c|c|c|c|c|}
\hline & \multicolumn{4}{|c|}{ Azufrada } & \multicolumn{4}{|c|}{ Playa Blanca } \\
\hline & n & $\begin{array}{c}\mathrm{LCC} / \mathrm{CCL} \\
\text { (media/mean } \\
\pm \mathrm{SD})\end{array}$ & $\begin{array}{c}\mathrm{LRC} / \mathrm{SCL} \\
\text { (media/mean } \\
\pm \mathrm{SD})\end{array}$ & $\begin{array}{c}\text { Peso/Weight } \\
\text { (media/mean } \\
\pm \text { SD) }\end{array}$ & $\mathbf{n}$ & $\begin{array}{c}\mathrm{LCC} / \mathrm{CCL} \\
\text { (media/mean } \\
\pm \mathrm{SD})\end{array}$ & $\begin{array}{c}\mathrm{LRC} / \mathrm{SCL} \\
\text { (media/mean } \\
\pm \mathrm{SD})\end{array}$ & $\begin{array}{l}\text { Peso/Weight } \\
\text { (media/mean } \\
\quad \pm \text { SD) }\end{array}$ \\
\hline Categoría 1/Category 1 (30-34.9 cm) & 4 & $33.1 \pm 0.8$ & $31.3 \pm 1.2$ & $3.8 \pm 0.3$ & 2 & $34.9 \pm 0.1$ & $33.1 \pm 0.2$ & $4.5 \pm 0.7$ \\
\hline Categoría 2/Category $2(35-39.9 \mathrm{~cm})$ & 7 & $38.4 \pm 0.7$ & $36.6 \pm 1.3$ & $5.9 \pm 0.5$ & 9 & $38-2 \pm 0.8$ & $36.0 \pm 1.2$ & $6.3 \pm 1.2^{*}$ \\
\hline Categoría 3/Category $3(40-44.9 \mathrm{~cm})$ & 5 & $42.2 \pm 1.0$ & $38.9 \pm 2.9$ & $8.0 \pm 0.8^{*}$ & 10 & $42.1 \pm 1.2$ & $39.8 \pm 1.5$ & $8.0 \pm 0.8$ \\
\hline Categoría 4/Category 4 (45-49.9 cm) & 1 & $45.6 \pm 0.0$ & $43.0 \pm 0.0$ & $11.0 \pm 0.0$ & 7 & $48.4 \pm 0.8$ & $45.7 \pm 0.7$ & $12.3 \pm 0.6$ \\
\hline Categoría 5/Category $5(\mathrm{LCC} / \mathrm{CCL} \geq 50 \mathrm{~cm})$ & 2 & $50.0 \pm 0.0$ & $45.4 \pm 1.2$ & $13.3 \pm 1.1$ & 2 & $54.0 \pm 5.7$ & $49.6 \pm 6.4$ & $17.4 \pm 0.8$ \\
\hline Total & 19 & $39.9 \pm 5.1$ & $35.9 \pm 4.6$ & $8.0 \pm 3.4$ & 30 & $44.5 \pm 6.5$ & $38.9 \pm 5.4$ & $10.7 \pm 8.0$ \\
\hline
\end{tabular}




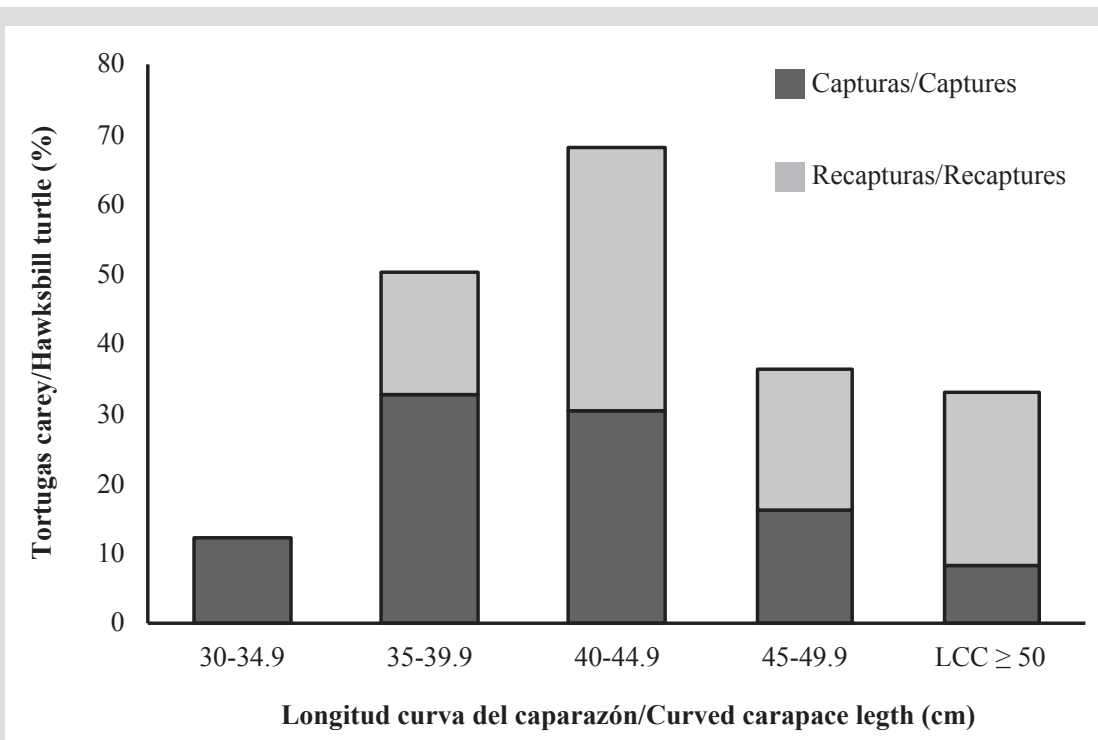

Figura 2. Porcentaje de individuos de tortugas carey, Eretmochelys imbricata, capturados en cada categoría de talla (LCC) en ambos arrecifes del PNNG entre 2004 y 2018.
Figure 2. Percentage of individuals of hawksbill turtles, Eretmochelys imbricata, captured in each size category $(\mathrm{CCL})$ on both reefs of the GNNP between 2004 and 2018.

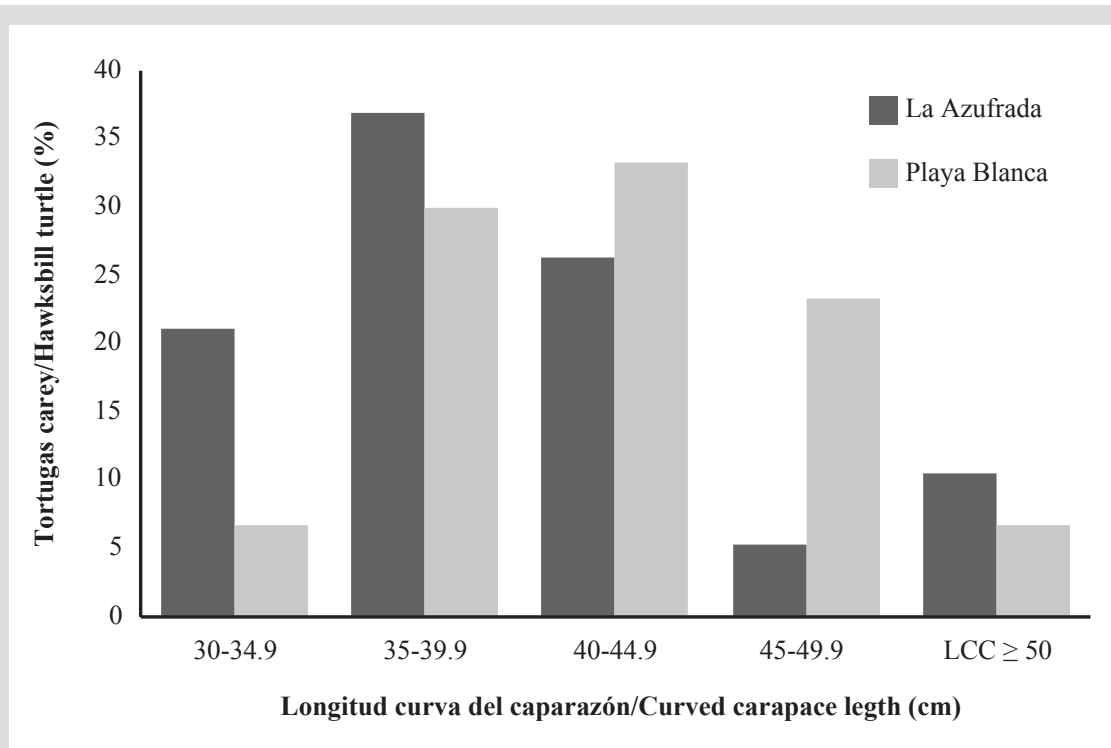

Figura 3. Porcentaje de individuos de tortugas carey, Eretmochelys imbricata, capturados por primera vez en cada categoría de talla (LCC) en cada arrecife coralino del PNNG entre 2004 y 2018.
Figure 3. Percentage of individuals of hawksbill turtles, Eretmochelys imbricata, captured for the first time in each size category (CCL) captured on each coral reef of the GNNP between 2004 and 2018.
En el análisis de crecimiento somático, el menor $C V$ se obtuvo con una longitud máxima de $63 \mathrm{~cm}$ LCC $(C V=0,96)$, y arrojó un promedio de coeficiente característico de crecimiento corporal $(k)$ de 0,081 . La curva de crecimiento de von Bertalanffy indicó que los individuos en esta población alcanzarían esta talla entre los 33 y 34 años de edad (Figura 4). Además, se estimó una TCC anual de 1,5 $\pm 1,8 \mathrm{~cm} /$ año (rango $0-7,3 \mathrm{~cm} /$ año). this height between 33 and 34 years of age (Figure 4). In addition, an annual BGR of $1.5 \pm 1.8 \mathrm{~cm} /$ year (range $0-7.3 \mathrm{~cm} /$ year) was estimated. 


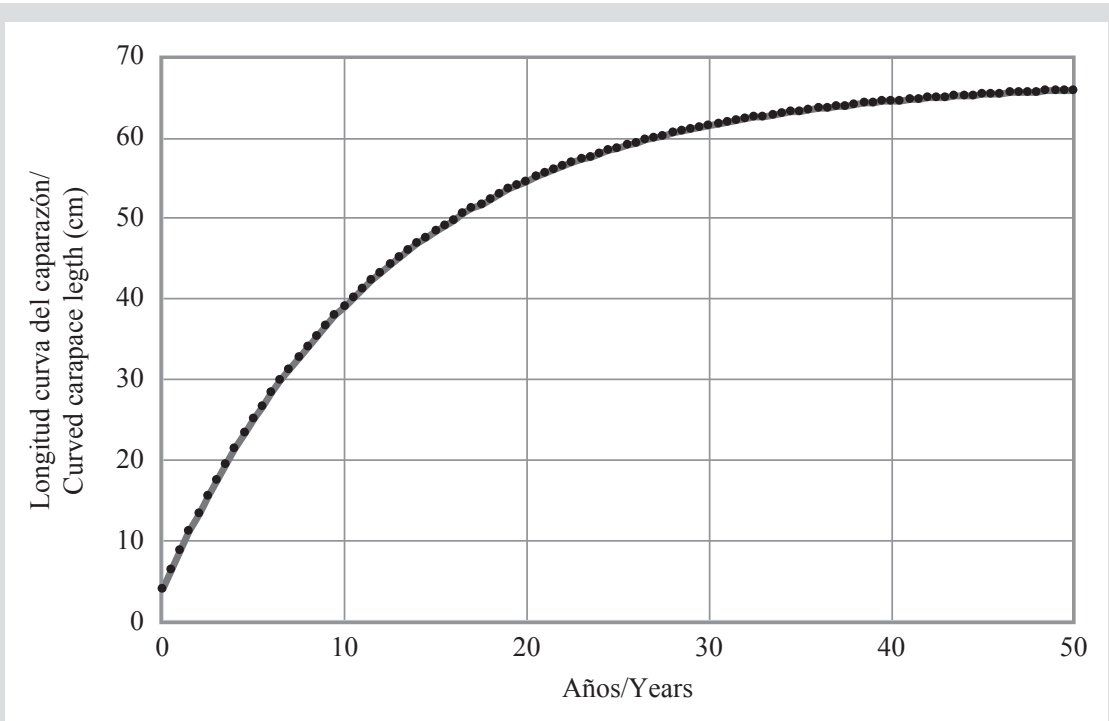

Figura 4. Curva del modelo de crecimiento de von Bertalanffy para la agregación de tortuga carey, Eretmochelys imbricata, en el PNNG entre 2004 y 2018.
Figure 4. Von Bertalanffy growth model curve for the hawksbill turtle aggregation, Eretmochelys imbricata, in the GNNP between 2004 and 2018.

\section{DISCUSIÓN}

Las tortugas carey halladas en este estudio son inmaduras debido a que no superan los $66 \mathrm{~cm} \mathrm{LCC,} \mathrm{longitud}$ mínima descrita para hembras reproductivas en el OPO (Witzell, 1983; Altamirano et al., 2010; Chacón-Chaverri et al., 2015) ni la registrada para machos (LRC $>68 \mathrm{~cm}$, Diez y van Dam, 2002). El rango de longitud curva del caparazón documentado $(32-60 \mathrm{~cm})$ es similar al que se encontró en otras áreas de forrajeo en el Pacífico, como el Parque Nacional Coiba, Panamá (Tabla 3; Llamas et al., 2017) y Golfo Dulce, Costa Rica $(34,8$ y $81,1 \mathrm{~cm}$ de LCC; Chacón-Chaverri et al., 2015). Adicionalmente, la distribución de categorías de talla (32,7 \% entre 35 y $39,9 \mathrm{~cm}$ LCC) fue similar a la hallada por Llamas et al. (2017) en Panamá y al anterior estudio realizado en el PNNG por Tobón-López y Amorocho (2014). No se encontró una diferencia estadísticamente significativa en las proporciones de categorías entre ambos arrecifes, lo que indica que la talla de las tortugas carey es independiente del arrecife. El hecho de haber capturado cuatro individuos pequeños (categoría 1 entre 30 y $34,9 \mathrm{~cm}$ LCC) $\sin$ marcar entre 2014 y 2018 podría estar indicando el reclutamiento continuo de nuevos individuos a esta zona de forrajeo. Todo esto nos sugiere que los arrecifes del PNNG proveen un hábitat de desarrollo y forrajeo importante para esta especie, y que la ausencia de individuos adultos insinúa una migración a otras áreas de reproducción y forrajeo al transitar de inmaduros a adultos durante su desarrollo, como lo sugieren Tobón-López y Amorocho (2014).

\section{DISCUSSION}

The hawksbill turtles found in this study are immature because they do not exceed $66 \mathrm{~cm}$ CCL, the minimum length described for reproductive females in the EPO (Witzell, 1983; Altamirano et al., 2010; Chacón-Chaverri et al., 2015) or that reported for males ( $\mathrm{SCL}>68 \mathrm{~cm}$, Diez and van Dam, 2002). The documented curved carapace length range $(32-60 \mathrm{~cm})$ is similar to that found in other foraging areas on the Pacific, such as Coiba National Park, Panama (Table 3; Llamas et al., 2017) and Golfo Dulce, Costa Rica (34.8 and $81.1 \mathrm{~cm}$ of CCL; Chacón-Chaverri et al., 2015). Additionally, the distribution of height categories (32.7\% between 35 and $39.9 \mathrm{~cm} \mathrm{CCL)}$ was similar to that found by Llamas et al., (2017) in Panama and the previous study carried out in the GNNP by TobónLópez and Amorocho (2014). No statistically significant difference was found in the category proportions between the two reefs, indicating that the size of hawksbill turtles is independent of the reef. The fact of having captured four small individuals (category 1 between 30 and $34.9 \mathrm{~cm} \mathrm{CCL}$ ) unmarked between 2014 and 2018, could be indicating the continuous recruitment of new individuals to this foraging area. All this suggests that the reefs of the GNNP provide an important development and foraging habitat for this species and that the absence of adult individuals suggests a migration to other breeding and foraging areas when they move from immature to adults during their development, as suggested by Tobón-López and Amorocho (2014). 
Dado que $98 \%$ de los individuos marcados y liberados en la playa de El Poblado fueron recapturados en el mismo arrecife, se insinúa la fidelidad de las tortugas carey a cada arrecife del PNNG, como lo mencionan Tobón-López y Amorocho (2014), y se evidencia la residencia a largo plazo de algunos individuos (recaptura de un individuo después de 10 años). La fidelidad de las tortugas carey a las áreas de forrajeo ha sido documentada en otros estudios (CarriónCortez et al., 2013; Wood et al., 2013; Llamas et al., 2017). Solo se observó un caso en el que el individuo fue capturado cuatro veces durante el año 2011 en ambos arrecifes. Esto pudo deberse a la conectividad entre los dos arrecifes, ya que se ubican relativamente cerca. Por otra parte, no se encontraron individuos marcados previamente en otras áreas de forrajeo ni tortugas marcadas en el PNNG en otras áreas de forrajeo o de anidación en países vecinos donde se ha realizado marcaje y monitoreo (Altamirano et al., 2010; Liles et al., 2011; Carrión-Cortez et al., 2013; Heidemeyer et al., 2014; Chacón-Chaverri et al., 2015; Llamas et al., 2017). Lo anterior advierte sobre la importancia de proteger el área de forrajeo para esta agregación y sugiere que se debe continuar con el monitoreo en el OPO para lograr identificar rutas de migración y complementar los planes de conservación regionales de la población de tortugas carey.

El ICC $(1,3 \pm 0,11)$ indica que la agregación de tortuga carey presente en esta área protegida se encuentra en buen estado físico y de salud, ya que es ligeramente superior a los índices estimados en la región del Caribe, como en Little Cayman $(1,25 \pm 0,17)$ y Grand Cayman $(1,24 \pm 0,18$; Blumenthal et al., 2009); en el arrecife Mona $(1,18)$, el acantilado Mona $(1,16)$ y el acantilado Monito $(1,24)$ en Puerto Rico (Diez y van Dam, 2002), y en la reserva Union Creek (1,17 $\pm 0,08)$, en Bahamas (Bjorndal y Bolten, 2010), donde se registra un buen estado de las tortugas carey. A pesar de que la región del OPO se encuentra fuertemente influenciada por el desplazamiento latitudinal de la Zona de Convergencia Intertropical (ZCIT) y el fenómeno de El Niño, los cuales influyen en las condiciones climáticas y oceanográficas del PNNG (Zapata, 2017), que podría tener efectos en la disponibilidad de alimento, el ICC indica que la población permanece saludable y no tiene déficit de alimentos. Por otra parte, aunque una de las mayores perturbaciones físicas en los arrecifes del PNNG son las repetidas exposiciones aéreas durante las mareas bajas extremas, las cuales disminuyeron considerablemente la cobertura de coral vivo entre 1998 y 2008, esta cobertura coralina se ha recuperado (Zapata, 2017), lo que indica que
Given that $98 \%$ of the individuals tagged and released at El Poblado Beach were recaptured on the same reef, the fidelity of hawksbill turtles to each reef of the GNNP is hinted at, as mentioned by Tobón-López and Amorocho (2014) and the long-term residence of some individuals is evidenced (recapture of an individual after 10 years). The fidelity of hawksbill turtles to foraging areas has been documented in other studies (Carrión-Cortez et al., 2013; Wood et al., 2013; Llamas et al., 2017). Only one case was observed in which the individual was captured four times during 2011 in both reefs. This could be due to the connectivity between the two reefs since they are located relatively close. On the other hand, no previously tagged individuals were found in other foraging areas and turtles tagged in the GNNP were found in other foraging or nesting areas in neighboring countries where tagging and monitoring have been carried out (Altamirano et al., 2010; Liles et al., 2011; Carrión-Cortez et al., 2013; Heidemeyer et al., 2014; Chacón-Chaverri et al., 2015; Llamas et al., 2017). This warns of the importance of protecting the foraging area for this aggregation and suggests that monitoring should continue in the EPO to identify migration routes and complement regional conservation plans for the hawksbill population.

The BCI $(1.3 \pm 0.11)$ indicates that the hawksbill aggregation present in this protected area is in good physical and health condition since it is slightly higher than the indices estimated in the Caribbean region, such as in Little Cayman $(1.25 \pm 0.17)$ and Grand Cayman (1.24 \pm 0.18 ; Blumenthal et al., 2009); in the Mona reef (1.18), the Mona cliff (1.16) and the Monito cliff (1.24) in Puerto Rico (Diez and van Dam, 2002), and in the Union Creek Reserve (1.17 \pm 0.08$)$, in Bahamas (Bjorndal and Bolten, 2010), where a good state of hawksbill turtles is reported. Even though the EPO region is strongly influenced by the latitudinal displacement of the Intertropical Convergence Zone (ITCZ) and by the El Niño phenomenon, which influences the climatic and oceanographic conditions of the GNNP (Zapata, 2017) that could have effects on food availability, the BCI indicates that the population remains healthy and does not have a food deficit. On the other hand, although one of the major physical disturbances in the reefs of the GNNP is the repeated aerial exposures during extreme low tides, which considerably decreased the live coral cover between 1998 and 2008, this coral cover has recovered (Zapata, 2017), which indicates that this phenomenon should not affect the development of hawksbill turtles in this foraging area. The BCI suggests that 
este fenómeno no debe afectar el desarrollo de las tortugas carey en esta área de forrajeo. El ICC sugiere que las condiciones ambientales que se presentan en los arrecifes del PNNG son ideales para mantener en buen estado la salud de esta agregación de tortugas, lo cual reafirma que esta es un área de forrajeo importante para la conservación de la especie en la región del OPO.

El coeficiente característico de crecimiento corporal $(k)$ estimado en este estudio $(0,081)$ es comparable con el valor encontrado $(0,09)$ por Snover et al. (2012) para tortugas carey en Hawái por medio de esqueletocronología, donde se sugiere que las tortugas de esa población alcanzarán la madurez sexual con una LRC de 78,6 cm entre los 17 y 22 años de edad. En otros estudios realizados con tortugas marinas utilizando el modelo de von Bertalanffy, se han registrado para Chelonia mydas valores de $k$ entre 0,021 (costa atlántica de EE. UU; Goshe et al., 2010) y 0,21 (bahía San Diego, CA, EE. UU.; Eguchi et al., 2012); para Caretta caretta valores de $k$ entre 0,044 (costa atlántica de Florida; Bjorndal et al., 2001) y 0,769 (costas de Italia; Casale et al., 2009), y para Lepidochelys kempii valores de $k$ entre 0,115 (costa atlántica de Florida) y 0,25 (golfo de México; Avens et al., 2017). Con el valor de $k$ que se estimó en este estudio por medio de la curva de von Bertalanffy, los individuos de esta agregación podrían tardar alrededor de 33-34 años en alcanzar una LCC de $63 \mathrm{~cm}$ (Figura 4), cerca de la talla mínima de madurez para las hembras registrada para el OPO (Witzell, 1983; Altamirano et al. 2010; Chacón-Chaverri et al., 2015). Esta estimación es mayor a la registrada para las tortugas carey en Hawái por Snover et al. (2012), pero comparable a la de Bjorndal y Zug (1995) y Bell y Pike (2012) en el norte de la GBR (Australia), la cual se estimó entre 30 y 40 años. Esto nos indica que la tasa de crecimiento somático de los individuos capturados en el PNNG está dentro de los rangos estimados para otras poblaciones de esta especie. Por otra parte, en este estudio se halló una TCC de 1,5 cm/año (rango 0-7,3 cm/año), la cual es menor a la tasa promedio de las demás tasas estimadas en otras regiones del Pacífico oriental, occidental y del Caribe (Tabla 3). Sin embargo, el rango en la TCC (0-7,3 cm/año) está dentro del observado en el Atlántico occidental $(-2,1-$ 22,6 cm/año; Bjorndal et al., 2016).

Las bajas tasas de crecimiento somático en la tortuga carey en comparación con las de otras tortugas marinas como $C$. caretta y L. olivácea pueden estar asociadas a una gran variedad de factores, tanto intrínsecos del individuo (coevolución con otros atributos de su historia the environmental conditions that occur in the reefs of the GNNP are ideal to maintain the health of this aggregation of turtles in good condition, which reaffirms that this is an important foraging area for the conservation of the species in the EPO region.

The characteristic coefficient of body growth $(k)$ estimated in this study (0.081) is comparable with the value found (0.09) by Snover et al. (2012) for hawksbill turtles in Hawaii using skeletochronology, where it suggests that turtles in this population will reach sexual maturity with an SCL of $78.6 \mathrm{~cm}$ between 17 and 22 years of age. In other studies carried out with sea turtles using the von Bertalanffy model, for Chelonia mydas has been reported values of $k$ between 0.021 (US Atlantic Coast; Goshe et al., 2010) to 0.21 (San Diego Bay, California; Eguchi et al., 2012), for Caretta caretta values of $k$ between 0.044 (Atlantic coast of Florida; Bjorndal et al., 2001) and 0.769 (coast of Italy; Casale et al., 2009), and for Lepidochelys kempii values of $k$ between 0.115 (Florida Atlantic coast) and 0.25 (Gulf of Mexico; Avens et al., 2017). With the value of $k$ that was estimated in this study using the von Bertalanffy curve, individuals in this aggregation could take around 3334 years to reach a CCL of $63 \mathrm{~cm}$ (Figure 4), close to the minimum size of maturity for females reported for the EPO (Witzell, 1983; Altamirano et al., 2010; Chacón-Chaverri et al., 2015). This estimate is higher than that reported for hawksbill turtles in Hawaii by Snover et al. (2012), but comparable to Bjorndal and Zug (1995) and Bell and Pike (2012) in the northern GBR (Australia), which was estimated between 30 and 40 years. This indicates that the somatic growth rate of the individuals captured in the GNNP is within the ranges estimated for other populations of this species. On the other hand, this study found a BGR of $1.5 \mathrm{~cm} /$ year (range $0-7.3 \mathrm{~cm} /$ year), which is lower than the average rate of the other rates estimated in other regions of the Eastern, Western and Caribbean Pacific (Table $3)$. However, the range in BGR $(0-7.3 \mathrm{~cm} /$ year $)$ is within the observed in the Western Atlantic (-2.1-22.6 cm/year; Bjorndal et al., 2016).

The low somatic growth rates in the hawksbill turtle compared to other sea turtles such as $C$. caretta and L. olivácea, may be associated with a great variety of factors, both intrinsic to the individual (co-evolution with other attributes of its life history, phylogenetic restrictions, genetic variability, among others) as extrinsic (temperature, feeding), which affect growth in sea turtles (Sterns, 1992; Diez and van Dam, 2002; Bell and Pike, 2012). Because the 
de vida, restricciones filogenéticas, variabilidad genética, entre otros) como extrínsecos (temperatura, alimentación), que afectan el crecimiento en tortugas marinas (Sterns, 1992; Diez y van Dam, 2002; Bell y Pike, 2012). Debido a que el ICC sugiere que esta agregación se encuentra en un área de forrajeo adecuada para el buen desarrollo de la tortugas carey, el PNNG fue declarado área marina protegida desde 1984 y los arrecifes Playa Blanca y La Azufrada han permanecido cerrados al público no científico durante los últimos años, ya que son considerados Valores Objeto de Conservación. La principal causa de estas tasas de crecimiento somático lentas es su tipo de historia de vida, ya que las tortugas marinas en general y E. imbricata en particular, se caracterizan por tener una edad de madurez sexual tardía y una expectativa de vida larga bajo condiciones naturales (Sterns, 1992; Lutz y Musick, 1997). Como una edad de madurez sexual tardía se correlaciona con tasas lentas de crecimiento poblacional (Doak et al., 1994) y tasas altas de sobrevivencia anual de los subadultos y adultos (Heppell et al., 1996; Heppell, 1998; Jonsson y Ebenman, 2001), una reducción sostenida en el valor de las tasas de sobrevivencia de estas dos clases puede conducir a la extinción local o global de la especie (Musick, 1999).
BCI suggests that this aggregation is in a suitable foraging area for the proper development of hawksbill turtles, the GNNP was declared a protected marine area since 1984 and the Playa Blanca and La Azufrada reefs have remained closed to the public. Not scientific during the last years, since they are considered Conservation Object Values. The main cause of these slow somatic growth rates is their type of life history, since sea turtles in general, and E. imbricata in particular are characterized by a late sexual maturity age and a long life expectancy, under natural conditions (Sterns, 1992; Lutz and Musick, 1997). As a late age of sexual maturity is correlated with slow population growth rates (Doak et al., 1994) and with high annual survival rates of sub-adults and adults (Heppell et al., 1996; Heppell, 1998; Jonsson and Ebenman, 2001), a sustained reduction in the value of the survival rates of these two classes can lead to the local or global extinction of the species (Musick, 1999).

Because the EPO is considered one of the Regional Management Units with the greatest threat to hawksbill turtles, it needs immediate attention both in reducing threats and in increasing monitoring for more rigorous evaluations of their risks and threats (Wallace et al.,
Tabla 3. Tasas de crecimiento corporal anual estimadas para diferentes poblaciones de Eretmochelys imbricata en diferentes regiones. *En algunos estudios se especifica la tasa de crecimiento por categoría de talla y por eso aparecen dos valores. Algunos estudios registran desviación estándar y otros no. **En este estudio fueron recapturados tres individuos.
Table 3. Estimated annual body growth rates for different populations of Eretmochelys imbricata in different regions. *In some studies the growth rate is specified by size category and therefore two values appear. Some studies report standard deviation and others do not. ${ }^{* *}$ Three individuals were recaptured in this study.

\begin{tabular}{|c|c|c|c|c|}
\hline Autor/Author & Área de estudio/Study area & Océano/Ocean & TCC/BGR* (cm/año) & Rango de talla/Size range $(\mathrm{cm})$ \\
\hline Llamas et al., 2017 & $\begin{array}{c}\text { Parque Nacional de la Isla de } \\
\text { Coiba, Panamá }\end{array}$ & $\begin{array}{l}\text { Pacífico oriental/ } \\
\text { Eastern Pacific }\end{array}$ & 2.8 & $30-75.5 \mathrm{~cm} \mathrm{LCC} / \mathrm{CCL}$ \\
\hline Zárate, 2015 & $\begin{array}{l}\text { Isla Galápagos/Galápagos } \\
\text { Island, Ecuador }\end{array}$ & $\begin{array}{l}\text { Pacífico oriental/ } \\
\text { Eastern Pacific }\end{array}$ & $7.9,2.4$ y $4.4^{* *}$ & $\begin{array}{l}\text { LCR promedio/mean SCL: } \\
46.9 \mathrm{~cm}, 63.6 \mathrm{~cm}, 70.7 \mathrm{~cm} * *\end{array}$ \\
\hline Limpus, 1992 & GBR, Australia & $\begin{array}{l}\text { Pacífico occidental/ } \\
\text { Western Pacific }\end{array}$ & $\begin{array}{l}1.39(40-50 \mathrm{~cm} \mathrm{LCC/CCL}) \text { y } \\
2.17(50-60 \mathrm{~cm} \mathrm{LCC/CCL})\end{array}$ & $39.5-87.5 \mathrm{~cm} \mathrm{LCC/CCL}$ \\
\hline Chaloupka y Limpus, 1997 & GBR, Australia & $\begin{array}{l}\text { Pacífico occidental/ } \\
\text { Western Pacific }\end{array}$ & $\begin{array}{c}1.8 \text { (hembras inmaduras/ } \\
\text { immature females) y } 1.2 \text { (machos } \\
\text { inmaduros/immature males) }\end{array}$ & $39-85 \mathrm{~cm} \mathrm{LRC/SCL}$ \\
\hline Bell y Pike, 2012 & GBR, Australia & $\begin{array}{l}\text { Pacífico occidental/ } \\
\text { Western Pacific }\end{array}$ & 1.26 & 61.3-91.4 cm LCC/CCL \\
\hline Bjorndal et al., 2016. & $\begin{array}{l}\text { Desde Bermudas hasta Brasil/ } \\
\text { Since Bermudas until Brasil }\end{array}$ & Caribe/The Caribbean & $3.1 \pm 2.3$ & 19-89.7 cm LRC/SCL \\
\hline Blumenthal et al., 2009 & Islas Cayman/Cayman Islands & Caribe/The Caribbean & $3.0 \pm 0.9$ & $20.5-62.6 \mathrm{~cm} \mathrm{LRC/SCL}$ \\
\hline Wood et al., 2013 & Palm Beach County, USA & Caribe/The Caribbean & 2.88 & $35.7-83.9 \mathrm{~cm} \mathrm{LRC/SCL}$ \\
\hline
\end{tabular}




\begin{tabular}{|c|c|c|c|c|}
\hline Autor/Author & Área de estudio/Study area & Océano/Ocean & TCC/BGR* (cm/año) & Rango de talla/Size range $(\mathrm{cm})$ \\
\hline Boulon, 1994 & $\begin{array}{c}\text { Islas Vírgenes/Virgin Islands, } \\
\text { USA }\end{array}$ & Caribe/The Caribbean & 3.48 & 27.4-60.7 cm LRC/SCL \\
\hline Diez y van Dam, 2002 & $\begin{array}{c}\text { Islas de Mona y Monito, } \\
\text { Puerto Rico }\end{array}$ & Caribe/The Caribbean & -0.59 y 9.08 & $20-84.5 \mathrm{~cm} \mathrm{LRC/SCL}$ \\
\hline Este estudio/This study & $\begin{array}{l}\text { Parque Nacional Natural } \\
\text { Gorgona, Colombia }\end{array}$ & $\begin{array}{l}\text { Pacífico oriental/ } \\
\text { Eastern Pacific }\end{array}$ & $1.5 \pm 1.8($ rango/range $0-7.3)$ & $\begin{array}{l}32.0-58.0 \mathrm{~cm} \mathrm{LCC/CCL} \\
30.0-54.1 \mathrm{~cm} \text { LRC/SSL }\end{array}$ \\
\hline
\end{tabular}

Debido a que el OPO es considerado como una de las Unidades de Manejo Regional con mayor amenaza para las tortugas carey, este necesita atención inmediata tanto en la reducción de las amenazas como en el incremento de los monitoreos para evaluaciones más rigurosas sobre sus riesgos y amenazas (Wallace et al., 2011). Para evidenciar si la población está en riesgo y fortalecer los planes de manejo es necesario conocer el estado demográfico de las poblaciones de tortugas marinas en las áreas de forrajeo por medio de la documentación de la dinámica con parámetros como abundancia y supervivencia (Bjorndal, 2000), los cuales son desconocidos para las poblaciones de tortuga carey en el OPO. En vista de que uno de los autores de este trabajo (LFP) estima que en al menos $20 \%$ de los episodios de búsqueda no se encontraron individuos, no se pudo utilizar el programa Mark para estimar estos parámetros, ya que estos datos no se encuentran en las bases de datos. Por esto, se recomienda que el monitoreo de esta especie se ejecute de forma sistemática (esfuerzos de tiempo y áreas de búsqueda consistentes entre años) y que los eventos de muestreo no exitosos (sin individuos capturados) sean registrados en dichas bases de datos. Con esta metodología, será posible estimar la probabilidad de supervivencia anual, la detectabilidad y la abundancia absoluta de la agregación de tortuga carey en los arrecifes coralinos de Playa Blanca y La Azufrada del Parque Natural Nacional Gorgona (PNNG).

\section{CONCLUSIONES}

Este estudio contribuye al conocimiento de características demográficas de la agregación de tortuga carey que habita dos arrecifes coralinos en el área protegida del PNNG en el OPO al presentar información necesaria para la conservación y el manejo de la especie en la región. Se evidencia que los arrecifes coralinos del PNNG son de gran valor como área de forrajeo para esta especie, ya que pueden mantener agregaciones productivas y saludables de tortugas carey basados en el índice de condición corporal, el cual se
2011). To show whether the population is at risk and to strengthen management plans, it is necessary to know the demographic status of the sea turtle populations in foraging areas by documenting the dynamics with parameters such as abundance and survival (Bjorndal, 2000). Which are unknown for the hawksbill populations in the EPO. Because one of the authors of this study (LFP) estimates that in at least $20 \%$ of the search episodes no individuals were found, the Mark program could not be used to estimate these parameters since these data are not found in databases. For this reason, it is recommended that the monitoring of this species be carried out systematically (time efforts and search areas consistent between years) and that unsuccessful sampling events (without captured individuals) be recorded in these databases. With this methodology, it will be possible to estimate the annual survival probability, the detectability, and the absolute abundance of the hawksbill turtle aggregation in the Playa Blanca and La Azufrada coral reefs of the Gorgona National Natural Park (GNNP).

\section{CONCLUSIONS}

This study contributes to the knowledge of the demographic characteristics of the hawksbill turtle aggregation that inhabits two coral reefs in the GNNP protected area in the EPO, presenting information necessary for the conservation and management of the species in the region. Evidently, the coral reefs of the GNNP are of great value as a foraging area for this species since they can maintain productive and healthy aggregations of hawksbill turtles based on the body condition index, which is close to the indices found in aggregations in the Caribbean. Also, the fidelity of these individuals to the coral reefs of the GNNP and their permanence for long periods during their development is observed. It is evident that these habitats are critical for the development of the juvenile hawksbill turtles of the Colombian Pacific. Since they spend a large part of their lives in neritic habitats, mainly on coral reefs, 
encuentra cerca de índices encontrados en agregaciones en el Caribe. Además, se observa la fidelidad de estos individuos a los arrecifes coralinos del PNNG y su permanencia en largos periodos durante su desarrollo. Esto pone en evidencia que estos hábitats son críticos para el desarrollo de las tortugas carey juveniles del Pacífico colombiano. Como pasan gran parte de sus vidas en hábitats neríticos, principalmente en arrecifes coralinos, y los esfuerzos centrados únicamente en playas de anidación pueden ser insuficientes (Lutz y Musick, 1997; Gaos et al., 2017; Llamas et al., 2017; Wildermann et al., 2018), se debe promover la protección de fuentes de mortalidad antropogénica como pesca incidental o choques con botes en la pesquería alrededor de esta región para la recuperación de la población.

Por otra parte, un componente clave para la evaluación de la viabilidad de las poblaciones es el conocimiento sobre su edad de madurez para establecer plazos de recuperación razonables en los planes de manejo. Este estudio presenta datos que evidencian la vulnerabilidad de esta especie debido a la madurez tardía y al crecimiento lento en esta agregación de tortugas marinas en el OPO, lo cual indica que los esfuerzos de conservación para esta especie deben ser a largo plazo para procurar su recuperación. Debido a que esta agregación se compone de individuos inmaduros y no se tienen datos de crecimiento para categorías de talla menores a $30 \mathrm{~cm}$ o superiores a $60 \mathrm{~cm}$ de LRC, esta extrapolación de crecimiento hasta la madurez debe interpretarse con cautela. Estudios con tortugas de agua dulce con edad conocida, por ejemplo, revelan que la remoción de individuos pequeños en los análisis genera cambios en la asíntota de la curva de crecimiento, lo cual también modifica la estimación de la edad de madurez (Bjorndal y Zug, 1995). La aproximación que se presenta en este estudio sobre la edad de madurez de las tortugas carey en el PNNG es importante como línea base para comparaciones futuras $\mathrm{y}$, asimismo, para fortalecer los planes de manejo de la especie en el OPO.

\section{AGRADECIMIENTOS}

Los autores agradecen al personal del Parque Nacional Natural Gorgona (PNNG) por realizar el monitoreo de tortugas marinas durante estos años, especialmente a Héctor Chirimía y a Ximena Zorrilla. Al Centro de Investigación para el Manejo Ambiental y el Desarrollo (CIMAD) y al Fondo Mundial para la Naturaleza (WWFColombia). Al Grupo Herpetológico de Antioquia y a la Universidad de Antioquia, especialmente a Brian C. Bock. and efforts focused solely on nesting beaches may be insufficient (Lutz and Musick, 1997; Gaos et al., 2017; Llamas et al., 2017; Wildermann et al., 2018), the protection of anthropogenic mortality sources such as bycatch or boat strikes in the fishery around this region should be promoted for the recovery of the population.

On the other hand, a key component for the evaluation of the viability of the populations is the knowledge about their age of maturity to establish reasonable recovery periods in the management plans. This study presents data that shows the vulnerability of this species due to late maturity and slow growth in this aggregation of sea turtles in the EPO, which indicates that conservation efforts for this species must be long-term to ensure its recovery. Since this aggregation is made up of immature individuals and there are no growth data for size categories less than $30 \mathrm{~cm}$ or greater than $60 \mathrm{~cm} \mathrm{SCL}$, this extrapolation of growth to maturity should be interpreted with caution. For example, studies with freshwater turtles with known age reveal that the removal of small individuals from the analysis causes changes in the asymptote of the growth curve, which also modifies the estimation of the age of maturity (Bjorndal and Zug, 1995). The approach presented in this study on the age of maturity of hawksbill turtles in the GNNP is important as a baseline for future comparisons and also to strengthen management plans for the species in the EPO.

\section{ACKNOWLEDGEMENT}

The authors thank the staff of the Gorgona Natural National Park (GNNP) for monitoring sea turtles during these years, especially Héctor Chirimía and Ximena Zorrilla. To the Research Center for Environmental Management and Development (CIMAD), and the World Wide Fund for Nature (WWF-Colombia). To the Herpetological Group of Antioquia and the University of Antioquia, especially Brian C. Bock. 


\section{BIBLIOGRAFÍA/LITERATURE CITED}

Altamirano, E.J. 2010. Informe final de proyecto de conservación de tortuga carey (Eretmochelys imbricata) en la RN Estero Padre Ramos, temporada 2010. Nicaragua: Flora y Fauna Internacional.

Amorocho, D.F., J.A. Rodríguez-Zuluaga, L.F. Payán, L.A. Zapata y P.A. Rojas. 2015. Plan de manejo de las tortugas marinas del Parque Nacional Natural Gorgona. Parques Nacionales Naturales, Cali. 88 p.

Avens, L., L.R. Goshe, L. Coggins, D.J. Shaver, B. Higgins, A.M. Landry, and R. Bailey. 2017. Variability in age and size at maturation, reproductive longevity, and long-term growth dynamics for Kemp's Ridley sea turtles in the Gulf of Mexico. PLoS ONE, 12: 1-25. https://doi.org/10.1371/journal. pone.0173999

Balazs, G.H. 2000. Factores a considerar en el marcado de tortugas marinas. 116-125. En: Eckert, K.L., K.A. Bjorndal, F.A. Abreu-Grobois y M. Donnelly (Eds). Técnicas de investigación y manejo para la conservación de las tortugas marinas. Grupo Especialista en Tortugas Marinas UICN/CSE, Washington, D. C. 270 p.

Bell, I. and D.A. Pike. 2012. Somatic growth rates of Hawksbill Turtles Eretmochelys imbricata in a northern Great Barrier Reef foraging area. Mar. Ecol. Progr. Ser., 446: 275-283. https://doi.org/10.3354/meps09481.

Bjorndal, K.A. 2000. Prioridades para la investigación en hábitats de alimentación. 13-15. En: Eckert, K.L., K.A. Bjorndal, F.A. Abreu-Grobois y M. Donnelly (Eds). Técnicas de investigación y manejo para la conservación de las tortugas marinas. Grupo Especialista en Tortugas Marinas UICN/CSE, Washington, D. C. 270 p.

Bjorndal, K.A. and A.B. Bolten. 2010. Hawksbill sea turtles in seagrass pastures: success in a peripheral habitat. Mar. Biol., 157: 135-145. https://doi. org/10.1007/s00227-009-1304-0

Bjorndal, K.A. and G. Zug. 1995. Growth and age of sea turtles. 599-603. In: K.A. Bjorndal. (Ed). Biology and conservation of sea turtles. Smithsonian Institution Press, Washington and London. 615 p.

Bjorndal, K.A., A.B. Bolten, B. Koike, B.A. Schroeder, D.J. Shaver, W.G. Teas, and W.N. Witzell. 2001. Somatic growth function for immature loggerhead sea turtles, Caretta caretta, in southeastern U.S. waters. Fish. Bull., 99: 240-246.

Bjorndal, K.A., M. Chaloupka, V.S. Saba, C.E. Diez, R.P. van Dam, B.H. Krueger, et al. 2016. Somatic growth dynamics of west Atlantic hawksbill sea turtles: a spatio-temporal perspective. Ecosphere, 7: 1-14. https://doi.org/10.1002/ecs2.1279

Blumenthal, J.M., T.J. Austin, C.D.L. Bell, J.B. Bothwell, A.C. Broderick, G. Ebanks-Petrie, J.A. Gibb, K.E. Luke, J.R. Olynik, M.F. Orr, J.L. Solomon, and B.J. Godley. 2009. Ecology of Hawksbill Turtles, Eretmochelys imbricata, on a western Caribbean foraging ground. Chelonian Cons. Biol., 8: 1-10. https://doi.org/10.2744/ccb-0758.1

Bolten, A.B. 2000. Técnicas para la medición de tortugas marinas. 126-131. En: Eckert, K.L., K.A. Bjorndal, F.A. Abreu-Grobois y M. Donnelly (Ed). Técnicas de investigación y manejo para la conservación de las tortugas marinas. Grupo Especialista en Tortugas Marinas UICN/CSE, Washington, D. C. 270 p.

Boulon, R.H. 1994. Growth rates of wild juvenile Hawksbill Turtles, Eretmochelys imbricata, in St. Thomas, United States Virgin Islands. Copeia, 3: 811814. https://doi.org/10.2307/1447200

Campbell, C.L. 2014. Estado de conservación de la tortuga carey en las regiones del Gran Caribe, Atlántico occidental y Pacífico Oriental. Secretaría Pro Tempore CIT, Virginia, EE. UU. 76 p.

Carrión-Cortez, J., C. Canales-Cerro, R. Arauz, and R. Riosmena-Rodríguez. 2013. Habitat use and diet of juvenile Eastern Pacific Hawksbill Turtles (Eretmochelys imbricata) in the north Pacific coast of Costa Rica. Chelonian Cons. Biol., 12: 235-245. https://doi.org/10.2744/ccb-1024.1

Casale, P., P.P. D'Astore, and R. Argano. 2009. Age at size and growth rates of early juvenile loggerhead sea turtles (Caretta caretta) in the Mediterranean based on length frequency analysis. Herpetol. J., 19: 29-33.

Chacón-Chaverri, D., D.A. Martínez-Cascante, D. Rojas y L.G. Fonseca. 2015. Golfo Dulce, Costa Rica, un área importante de alimentación para la tortuga carey del Pacífico Oriental (Eretmochelys imbricata). Rev. Biol. Trop., 63: 351-362. https://doi.org/10.15517/rbt.v63i1.23114

Chaloupka, M.Y. and C.J. Limpus. 1997. Robust statistical modelling of hawksbill sea turtle growth rates (southern Great Barrier Reef). Mar. Ecol. Progr. Ser., 146: 1-8. https://doi.org/10.3354/meps146001.

Diez, C.E. and R.P. van Dam. 2002. Habitat effect on hawksbill turtle growth rates on feeding grounds at Mona and Monito Islands, Puerto Rico. Mar. Ecol. Progr. Ser., 234: 301-309. https://doi.org/10.3354/meps234301. 
Doak, D., Kareiva, P., and Klepetka, B. 1994. Modeling population viability for the Desert Tortoise in the western Mojave desert. Ecol. Appl., 4: 446-460.

Eguchi, T., J.A. Seminoff, R.A. LeRoux, D. Prosperi, D.L. Dutton, and P.H. Dutton. 2012. Morphology and growth rates of the Green Sea Turtle (Chelonia mydas) in a northern-most temperate foraging ground. Herpetologica, 68: 76-87. https://doi.org/10.1655/herpetologica-d-11-00050.1

Fisher, R.A. 1934. Statistical methods for research workers. 5th ed. Oliver and Boyd, Edimburgh. 319 p.

Gaos, A.R., R.L. Lewison, I.L. Yáñez, B.P. Wallace, M.J. Liles, W.J. Nichols, A. Baquero, C.R. Hasbún, M. Vasquez, J. Urteaga, and J.A. Seminoff. 2012. Shifting the life-history paradigm: Discovery of novel habitat use by Hawksbill Turtles. Biol. Lett., 8: 54-56. https://doi.org/10.1098/rsbl.2011.0603

Gaos, A.R., M.J. Liles, V. Gadea, A.P. De Niz, F. Vallejo, C. Miranda, J.J. Darquea, A. Henríquez, E. Altamirano, A. Rivera, S. Chavarría, D. Melero, J. Urteaga, C.M. Pacheco, D. Chacón, C. LeMarie, J. Alfaro-Shigueto, J.C. Mangel, I.L. Yáñez, and J.A. Seminoff. 2017. Living on the edge: Hawksbill Turtle nesting and conservation along the Eastern Pacific Rim. Latin Am. J. Aq. Res., 45: 572-584. https://doi.org/10.3856/vol45-issue3-fulltext-7

Goshe, L.R., L. Avens, F.S. Scharf, and A.L. Southwood. 2010. Estimation of age at maturation and growth of Atlantic green turtles (Chelonia mydas) using skeletochronology. Mar. Biol., 157: 1725-1740. https://doi.org/10.1007/s00227-010-1446-0.0

Heidemeyer, M., R. Arauz-Vargas, and E. López-Agüero. 2014. New foraging grounds for hawksbill (Eretmochelys imbricata) and green turtles (Chelonia mydas) along the northern pacific coast of Costa Rica, Central America. Rev. Biol. Trop., 62: 109-118. https://doi.org/10.15517/rbt.v62i4.20037

Heppell, S.S. 1998. Application of life-history theory and population model analysis to turtle conservation. Copeia, 2(2): 367-375.

Heppell, S.S., L.B. Crowder, and D.T. Crouse. 1996. Models to evaluate headstarting as a management tool for long-lived turtles. Ecol. Appl., 6: 556-565.

Jonsson, A. y B. Ebenman. 2001. Are certain life histories particularly prone to local extinction? J. Theor. Biol., 209: 455-463.

Liles, M.J., M.V. Jandres, W.A. López, G.I. Mariona, C.R. Hasbún, and J.A. Seminoff. 2011. Hawksbill Turtles Eretmochelys imbricata in El Salvador: nesting distribution and mortality at the largest remaining nesting aggregation in the eastern Pacific Ocean. Endang. Spec. Res., 14: 23-30. https://doi. org/10.3354/esr00338

Limpus, C.J. 1992. The Hawksbill Turtle, Eretmochelys imbricata, in Queensland: population structure within a southern Great Barrier Reef feeding ground. Wildlife Res., 19: 489-506. https://doi.org/10.1071/WR9920489

Llamas, I., E.E. Flores, M.E. Abrego, J.A. Seminoff, C.E. Hart, R. Donadi, B. Peña, G. Álvarez, W. Poveda, D.F. Amorocho, and A. Gaos. 2017. Distribution, size range and growth rates of Hawksbill Turtles at a major foraging ground in the eastern Pacific Ocean. Latin Am. J. Aq. Res., 45: 597-605. https:// doi.org/10.3856/VOL45-ISSUE3-FULLTEXT-9

Lutz, P.L. and J.A. Musick. 1997. The biology of sea turtles. CRC Mar. Sci. Ser., Florida. 432 p.

Mortimer, J.A. and M. Donnelly. 2008. IUCN SSC Marine Turtle Specialist Group 2008. Eretmochelys imbricata. IUCN Red List Threat. Species. Version 2014.2. https://dx.doi.org/10.2305/IUCN.UK.2008.RLTS.T8005A12881238.en

Munro, J.L. 1982. Estimation of the parameters of the von Bertalanffy growth equation from recapture data at variable intervals. ICES J Mar. Sci., 40: 199200.

Muñoz, C. y F. Zapata. 2013. Plan de manejo de los arrecifes coralinos del Parque Nacional Natural Gorgona, Pacífico colombiano. Parques Nacionales Naturales y WWF-Colombia, Cali. 68 p.

Musick, J.A. 1999. Ecology and conservation of long-lived marine animals. 1-10. En: Musick, J.A. (Ed.). Life in the slow lane: ecology and conservation of long-lived marine animals. Am. Fish. Soc. Symp. 23, Bethesda, Maryland.

National Research Council. 1990. Decline of the sea turtles: causes and prevention. The National Academies Press, Washington, D. C. https://oi. org/10.17226/1536

Snover, M.L., G.H. Balazs, S.K.K. Murakawa, S.K. Hargrove, M.R. Rice, and W.A. Seitz. 2012. Age and growth rates of Hawaiian Hawksbill Turtles (Eretmochelys imbricata) using skeletochronology. Mar. Biol., 160: 37-46. https://doi.org/10.1007/s00227-012-2058-7

Tobón-López, A. y D.F. Amorocho. 2014. Estudio poblacional de la tortuga carey Eretmochelys imbricata (Cheloniidae) en el Pacífico sur de Colombia. Acta Biol. Col., 19: 447-457.

UICN. 2012. Categorías y criterios de la lista roja de la UICN: Versión 3.1. 2. ${ }^{\circ}$ ed. Gland, Suiza y Cambridge, Reino Unido: UICN. vi + 34 p.

Van Dam, R.P. 2000. Medición del crecimiento en tortugas marinas. 171-173. En: Eckert, K.L., K.A. Bjorndal, F.A. Abreu-Grobois y M. Donnelly (Eds). Técnicas de investigación y manejo para la conservación de las tortugas marinas. Grupo Especialista en Tortugas Marinas UICN/CSE, Washington, D. C. 270 p. 
Wallace, B.P., A.D. DiMatteo, A.B. Bolten, M.Y. Chaloupka, B.J. Hutchinson, F.A. Abreu-Grobois, et al. 2011. Global conservation priorities for marine turtles. PLoS One, 6: 1-4. https://doi.org/10.1371/journal.pone.0024510

Wildermann, N.E., C. Gredzens, L. Avens, H.A. Barrios-Garrido, I. Bell, J. Blumenthal, et al. 2018. Informing research priorities for immature sea turtles through expert elicitation. Endang. Spec. Res., 37: 55-76. https://doi.org/10.3354/esr00916

Witzell, W.N. 1983. Synopsis of biological data on the hawksbill turtle Eretmochelys imbricata (Linnaeus, 1766). FAO Fish. Synop., 1-78. https://doi. org/10.1016/0025-326x(84)90297-2

Wood, L.D., R. Hardy, P.A. Meylan, and A.B. Meylan. 2013. Characterization of a Hawksbill Turtle (Eretmochelys imbricata) foraging aggregation in a high-latitude reef community in southeastern Florida, USA. Herpetol. Cons. Biol., 8: 258-275.

Zárate, P.M, K.A. Bjorndal, J.A. Seminoff, P.H. Dutton, and A.B. Bolten. 2015. Somatic growth rates of Green Turtles (Chelonia mydas) and Hawksbills (Eretmochelys imbricata) in the Galápagos Islands. J. Herpetol., 49: 641-648.

Zapata, F.A. 2017. Temporal dynamics of coral and algal cover and their drivers on a coral reef of Gorgona Island, Colombia (Eastern Tropical Pacific). Rev. Acad. Col. Cienc. Exac., Fís. Nat., 41: 306-310. https://dx.doi.org/10.18257/raccefyn.486

RECIBIDO/RECEIVED: 30/07/2020

ACEPTADO/ACCEPTED: 03/10/2020 